\title{
Biological effects of alginite on tomato plants (Lycopersicon esculentum) and some insects (Leptinotarsa decemlineata, Galleria mellonella and Halyomorpha halys)
}

\author{
Dina Elisovețcaia"*, Raisa Ivanova ${ }^{1}$, Jana Šimková2 , Ján Brindza² \\ ${ }^{1}$ Institute of Genetics, Physiology and Plant Protection, Chisinau, Republic of Moldova \\ ${ }^{2}$ Slovak University of Agriculture in Nitra, Nitra, Slovak Republic \\ ORCID \\ Dina Elisovețcaia: https://orcid.org/0000-0003-0521-6428 \\ Raisa Ivanova: https://orcid.org/0000-0002-2554-2039 \\ Jana Šimková: https://orcid.org/0000-0001-5058-8832 \\ Ján Brindza: https://orcid.org/0000-0001-8388-8233
}

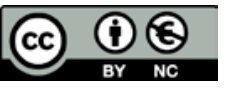

Article Details:

Received:

2021-10-01

Accepted:

2021-11-19

Available online: $2021-11-30$

DOI: https://doi.org/10.15414/ainhlq.2021.0033

\begin{abstract}
The purpose of our work was to study the effect of Slovak origin alginite on germination of tomato seeds, growth and development of plants, as well as to evaluate biological activity of alginite against to insect pests. Tomato seeds with low germination capacity were treated by immersion in alginite solutions of concentration $0.0001-0.1 \%$. Alginite solutions with concentrations of $0.1-5.0 \%$ were used for testing against insects. The application of alginite solutions significantly increases the germination of tomato seeds in laboratory conditions by $9.2-13.0 \%$. There was a significant increase in the length of seedlings and roots by $1.87-2.98 \mathrm{~cm}$ and $3.54-4.51 \mathrm{~cm}$. In a greenhouse presowing treatment of tomato seeds with $0.001 \%$ alginite solution significantly increased germination in comparison with the control (by $33.2 \%$ ) and 0.01 and $0.1 \%$ alginite solutions (by 22.2 and $25.0 \%$ ). Monitoring of plant height showed that a month after the first seedlings emergence the average plant height was significantly higher in the variant $0.001 \%$ alginite solution and reached to $11.41 \mathrm{~cm}$. The yield of fruits in the variants treated with alginite solutions significantly exceeded the control by 316.53-327.71 g per one tomato bush. It was found that alginite solutions at a concentration of 0.1-1.0\% had low ovicidal (2.73-13.19\%) and insecticidal (5.0-33.3\%) effects against insects belonging to different orders - Leptinotarsa decemlineata (Coleoptera), Galleria mellonella (Lepidoptera) and Halyomorpha halys (Hemiptera). Alginite solutions did not have contact insecticidal activity; the death of insects was caused mainly by the consumption of treated feed. At the same time, a high antifeedant effect was revealed from 45.0 to $85.0 \%$ against adults and larvae of 2-3 instars of L. decemlineata and larvae of 2-3 instars of G. mellonella. To conclude, the application of alginite contributed to an increase in seed germination and plant productivity, and it did not reveal significant biological activity against insects.
\end{abstract}

Keywords: alginite, seeds germination, plant growth, yield, insect biological activity

\footnotetext{
*Corresponding Author: Dina Elisovețcaia, Institute of Genetics, Physiology and Plant Protection, MD-2002, 20 Padurii str., Chisinau, Republic of Moldova $\triangle$ dina.elis.s@gmail.com
} 


\section{Introduction}

In modern conditions of climatic anomalies, it is extremely important to achieve stable production of high yields of significant agricultural crops. One of the leading places among vegetables belongs to tomatoes Lycopersicon esculentum Mill. Achieving high germination of seeds is possible with the integrated use of all agrotechnical methods, including the use of fertilizers, plant growth and development regulators. Alginite is considered one of the most promising materials with several of useful properties.

Alginite is an organic-bituminous rock, rich in macro- and microelements. Alginite arose as a result of the fossilization of accumulated organic (algae) and inorganic material, especially clay, carbonates, quartz and amorphous modification of silicic acid in the aqueous environment (Gancarčikova et al., 2019; Brindza et al., 2021a). In the Slovak Republic an alginite deposit (maar belonging to the Podrecany Basalt Formation, Pontian in age, approx. 6.5 m.y. B.C.), was discovered near Pinciná, close to the town of Lučenec, the center of the Novohrad region (Motyleva et al., 2014). Despite the fact that alginite contains trace elements, the toxicity of heavy metals is below the toxicity limit. The alginite has high water absorption capacity - up to $110 \%$ and high specific surface (313$654 \mathrm{~m}^{2}$ special features of the organic matter (kerogen type II) and by the presence of smectite (Brindza et al., 2021a). According to many authors, alginite, due to its exceptional chemical composition, improves the soil properties, thereby affecting the growth and development of plants, contributes to increase yields (Rauch and Földényi, 2012; Kádár et al., 2015; Benei and Rauch, 2016; Bednárová, 2019; Kropp et al., 2021).

The purpose of our work was to study the effect of Slovak origin alginite on germination of tomato seeds, growth and development of plants, as well as to evaluate biological activity of alginite against to insect pests.

\section{Material and methodology}

The experiments were carried out in laboratory conditions and in a greenhouse during 2020.

\section{Preparation of alginite solutions}

Alginite solutions at a concentration of $0.0001,0.001$, $0.01,0.1,1.0$ and $5.0 \%$ were prepared using distilled water in calibrated flasks. Alginite powder obtained from Slovak Republic was weighed on an analytical balance, and transferred quantitatively into a calibrated flask. Thereafter, the solution was thoroughly mixed and used immediately. The solution was thoroughly mixed before each use. Distilled water was used as a control.

\section{Effect of alginite solution on seed germination}

The influence of alginite on capacity of seed germination was studied in laboratory conditions using tomato seed with low germination rate. The seeds of tomatoes (Lycopersicon esculentum Mill.) were treated by immersion for 15 minutes in alginite solutions of concentration $0.0001,0.001,0.01$, and $0.1 \%$. Then the seeds were germinated for 10 days in Petri dishes between moistened filter paper disks in thermostat at temperature of $25^{\circ} \mathrm{C}$ (Rao et al., 2006, ISTA, 2017). Each variant consisted of four replicates, 100 seeds per replicate. Seeds treated with water served as a control. The total germination rate, the length of roots and seedlings were determined.

\section{Determination of the effect of alginite solutions on plant growth}

To determine the effect of alginite on growth of tomato plants, the tomato seeds were treated presowing by immersion for 24 hours in alginite solutions of concentration (0.1, 0.01 and $0.001 \%$ ). Treated seeds were sowed in greenhouse with drip irrigation in holes according to a randomized scheme. Each variant consisted of three replicates, 36 seeds per replicate. The indices of germination, plant height and yield from one tomatoes bush were analyzed.

\section{Determination of the biological activity of alginite solutions in relation to insect test-objects from the orders Coleoptera, Lepidoptera and Hemiptera}

The ovicidal, insecticidal and antifeedant properties of 0.1-5.0\% alginite solutions were determined according to standard methods in relation to insects belonging to different orders: Leptinotarsa decemlineata Say (Coleoptera), Galleria mellonella L. (Lepidoptera) and Halyomorpha halys Stal (Hemiptera) (Elisovetcaia et al., 2020). The contact effect of the extracts was determined by the method of topical application of $0.6 \mu \mathrm{l}$ of alginite solutions to the dorsal surface of insects. The intestinal effect of the extracts was determined by immersion a nutritive substrate (potato leaves) into alginite solutions, as well as by introducing alginite solutions of the appropriate concentration into an artificial nutrient medium (ANM). Variants with treatment using distilled water served as control. The calculation of ovicidal activity was carried out according to the correction for the number of sterile eggs in the control. 


\section{Statistical analysis}

Data analysis for determination of standard deviation, significant differences and correlation coefficients were performed by Statgraphics Plus 5.0 programme.

\section{Results and discussion}

The treatment with alginite solutions significantly increased the germination of tomato seeds in laboratory conditions in comparison with the control by $9.2-13.0 \%\left(\mathrm{LSD}_{0.05}=8.82, \mathrm{p} \leq 0.05\right)$ (Table 1$)$. The highest seed germination (81.3\%) was observed in the variant with the alginite concentration of 0.001 $\%$, the lowest $(77.5 \%)$ - in the variant with the 0.1 $\%$ alginite concentration. There was no significant difference between the variants with alginite solutions treatment of various concentrations, but it was found that with a decrease in concentration from 0.1 to 0.01 and $0.001 \%$, the germination of tomato seeds insignificantly increases - by 1.0 and $3.8 \%$, respectively. Seed germination in the variant with the $0.0001 \%$ alginite concentration is $1.3-2.3 \%$ less than in the variants 0.001 and $0.01 \%$, respectively, but at the same time it is $1.5 \%$ higher than in the $0.1 \%$ alginite variant and significantly exceeds the control (by $10.7 \%$ ).

Kovár et al. (2021) found that powder, crushed alginite and alginite extracts (sodium solution, potassium solution) have a positive effect on seeds germination of of Poa pratensis L., increasing the average germination in comparison with the control by $33.33-334.20 \%$, as well as alginite and its productsincreasethegermination rate by $0.04-1.52$ seeds/day in P. pratensis. These data are also confirmed by our results obtained with tomato seeds. Thus, it is obvious that different preparative forms of alginite promote better germination of seeds of various species of cultivated plants.

In our experiments, the treatment of tomato seeds with alginite solutions led to an increase in the length of seedlings and roots in all variants in comparison with the control. At the same time, the most significant increase in the length of seedlings by 18.7 and $29.8 \mathrm{~mm}$
$\left(\mathrm{LSD}_{0.05}=16.1, \mathrm{p} \leq 0.05\right)$ was observed in two variants at a concentration of alginite solutions of 0.01 and $0.1 \%$ (Table 1). A significant increase in root length by $22.2,35.4$ and $45.1 \mathrm{~mm}$ was observed in three variants of treatment with alginite solutions - with a concentration of $0.001,0.01$ and $0.1 \%$, respectively $\left(\mathrm{LSD}_{0.05}=15.5, \mathrm{p} \leq 0.05\right)$ (Table 1).

Thus, it was found that $0.1,0.01$, and $0.001 \%$ alginite solutions led to both a significant increase in the germination of tomato seeds and an increase in the length of seedlings and roots. Despite the fact that alginite at a concentration of $0.0001 \%$ contributes to a significant increase in seed germination, the difference in the length of roots and seedlings is insignificant in comparison with the control.

Therefore, for the presowing treatment of tomato seeds, it were selected three of the four tested concentrations - $0.1,0.01$ and $0.001 \%$ alginite solutions. The first seedlings emergence was noted on the $11^{\text {th }}$ day after sowing, the last - on the $19^{\text {th }}$ day after sowing.

The total germination of seeds in all variants of greenhouse experiments exceeded the control by 8.3-33.2 \%. However, a significant difference LSD $_{0.05}=$ $20.5, \mathrm{p} \leq 0.05$ ) was noted only in the variant where the seeds were treated with $0.001 \%$ alginite solution (Figure 1).

According to many authors (Ognjanova-Rumenova and Vaas, 1998; Vass, 1998; Kulich et al., 2001; Pichler et al., 2001; Brinza et al., 2021a), alginite contains a sufficient amount of humic acids, which, as heterogeneous organic compounds, are capable of improving soil fertility. Due to its water-saving properties, alginite is one of the best water-absorbing materials that can regulate the distribution of water towards the plant roots. Probably, these properties also play an important role in seed germination - supplying tomato seeds with nutrients, and retain and distribute moisture, thus creating optimal conditions for swelling and germination of seeds.

Table 1 Germination characteristics of tomato seeds treated with different concentrations of alginite

\begin{tabular}{lccc}
\hline Variants & Germination (\%) & Seedlings length (mm) & Roots length (mm) \\
\hline Control & 68.3 & 15.4 & 16.9 \\
Alginite $\mathbf{0 . 0 0 0 1 ~ \% ~}$ & 79.0 & 22.9 & 23.7 \\
Alginite 0.001 \% & 81.3 & 30.8 & 39.1 \\
Alginite 0.01 \% & 80.3 & 34.1 & 52.3 \\
Alginite 0.1 \% & 77.5 & 45.2 & 61.9 \\
LSD $_{\mathbf{0 . 0 5}}$ & 8.82 & 16.1 & 15.5 \\
\hline
\end{tabular}




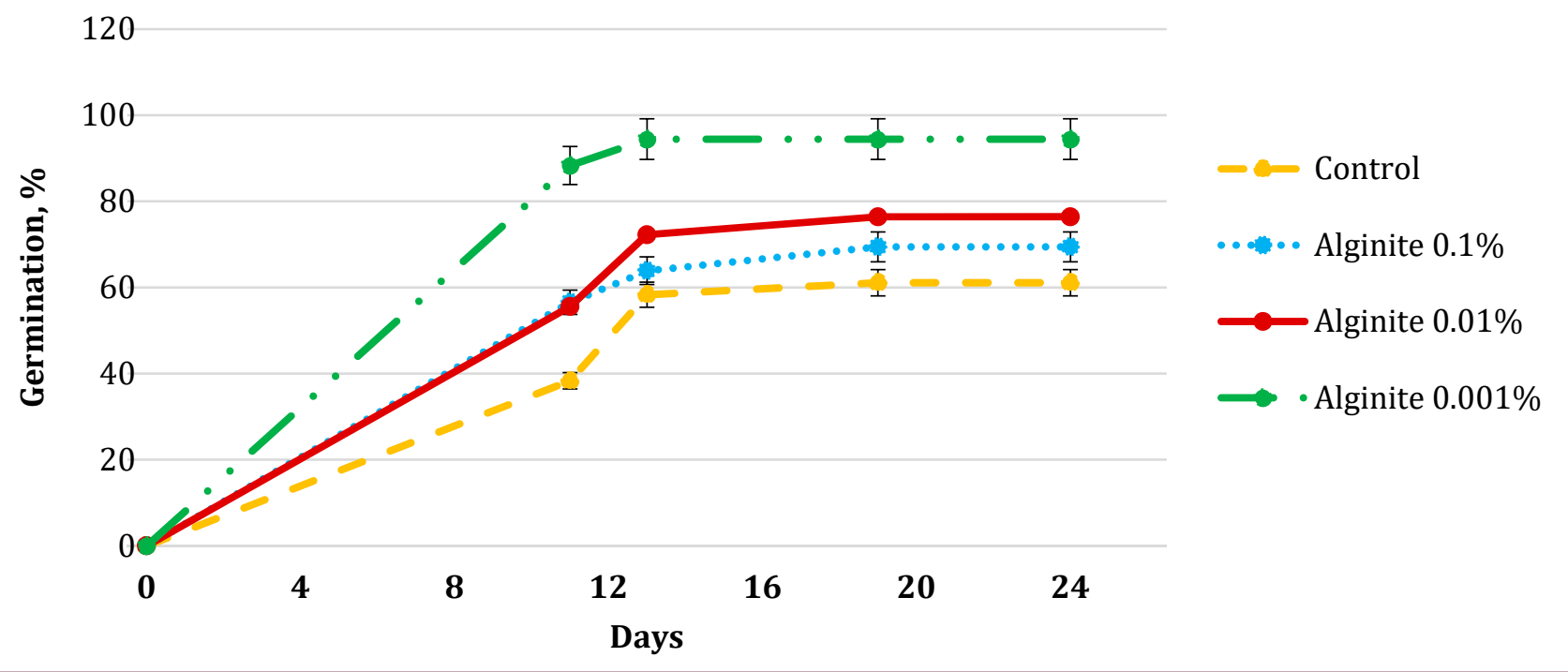

Figure 1 Germination rate of tomato seeds treated with alginite solutions in greenhouse conditions, 2020

Monitoring of plant height showed that a month after the first seedlings emergence the average of plant height was significantly higher in the variant $0.001 \%$ alginite solution and reached to $11.41 \mathrm{~cm}\left(\mathrm{LSD}_{0.05}=2.63\right.$, $\mathrm{p} \leq 0.05)$. The plant heights in other tested variants were at the control level $(8.21 \mathrm{~cm})$ (Figure 2).

In the experiment, ALGEX $_{\mathrm{r}} 6$ was applied by Horčinová Sedláčková et al. (2021) in the form of a watering in two variants with the same concentration of $3 \%$ solution in 2 deciliters of water, but various application in terms of days in the pre-harvest stage of the aboveground plant biomass of 30 individual plants from each species. There are two diametrically opposite trends of ALGEX $_{\mathrm{r}} 6$ application that are manifesting themselves in Melissa officinalis and Malva verticillata by reducing the root and above-ground part biomass compared to the control variant. The percentage proportionality of root/ above-ground part biomass in M. officinalis decreased from 62.48/30.31 \% (control), to $45.57 / 18.85 \%$ (variant 1) and to $36.07 / 17.27 \%$ (variant 2), as well as in $M$. verticillata the root/above-ground part biomass decreased from 16.03/13.93 \% (control) to $14.97 / 9.42 \%$ (variant 1 ) and to $11.61 / 10.14 \%$ (variant 2). In the species Ocimum $\times$ citriodorum Vis. the opposite trend manifested (Horčinová Sedláčková et al., 2021).

In our experiments, it was found that in the variant with the treatment with $0.1 \%$ alginite solution, the tomato plants looked depressed and lagged behind in growth from other variants by 2.51-5.71 cm. Also in this variant, within one and a half months after the appearance of the first seedlings, an average $30 \%$ of plants was died. Therefore, the variant of presowing

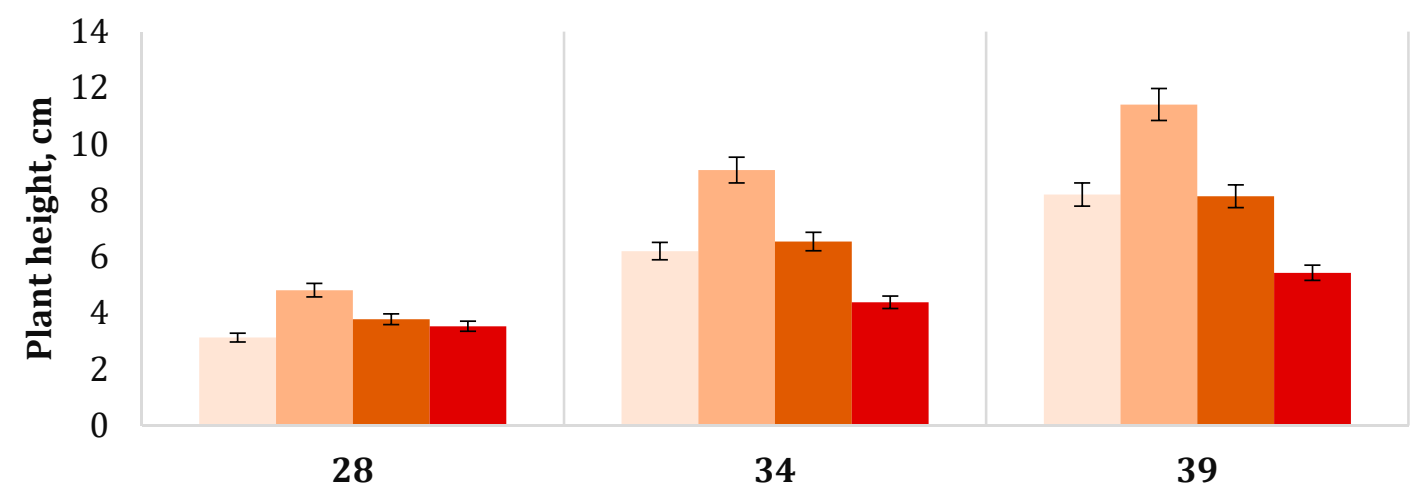

Days after seeds sowing

Control $\square$ Alginite $0.001 \% \quad \square$ Alginite $0.01 \% \quad \square$ Alginite $0.1 \%$

Figure 2 Height of tomato plants treated with alginite solutions in a greenhouse, 2020 
seeds treatment with $0.1 \%$ alginite solution was excluded from the experiment.

Cukor et al. (2017) studied growth parameters (height increment, mortality and foliar nutrient content) of Douglas fir (Pseudotsuga menziesii (Mirb.) Franco), Scots pine (Pinus sylvestris L.) and a mixture of English oak (Quercus robur L.), red oak (Quercus rubra L.) and Norway maple (Acer platanoides L.) seedlings on former agricultural land in central Bohemia, Czech Republic. The results showed that alginite application had greater positive effect on height growth of seedlings than mortality, especially variant C. In most of the cases height increments were significantly positively affected $(p<0.05)$ by both variants of alginite application only in the third year after planting.

Bio-Algeen system (materials based on the marine algae, both of fossil and recent origin) was tested by Kupka et al. (2015) at planting stock of Norway spruce production in a forest nursery. In the plantation experiment, significantly lower mortality was documented in the first year since planting, as well as significantly faster growth for broad-leaved species. In the nursery experiment, considerably more favourable development of the root system was detected as well as better parameters of the above-ground part of the planting stock. As the most effective, the combination of root dipping to Bio-Algeen water solution with granulate application on bed surface and also spraying of aboveground part of seedlings after transplanting were documented. Applications of studied material thus represent important contribution for quality stock production and plantation success on the forested site.

Biochar application to soils is being considered as means to improve fertility while concurrently improving soil functions. Based on results, authors found that biochar increased the microbial biomass values even before the incubation. In single and combined biochar-alginite treatments, more bacterial biomass was adsorbed due to the higher adhesion capability and the increased surface area. The volume of the microbial adsorption is different from species to species and even strains (Kocsis et al., 2020).

The spring and summer seasons of 2020 were characterized by extreme temperatures. Thus, already in the first decade of June, the temperature reached $27-35{ }^{\circ} \mathrm{C}$, and on some days $40-42{ }^{\circ} \mathrm{C}$. In July, the average daily temperatures were even higher, and in August, the mark reached an extreme value $45^{\circ} \mathrm{C}$. In the greenhouse, even with the use of shading green textile and ventilation, the temperature exceeded
$35{ }^{\circ} \mathrm{C}$ and often reached to $45{ }^{\circ} \mathrm{C}$ and more. These conditions significantly affected the ovary of plants. It is known that the pollination of tomato culture occurs mainly during the day, but the ripening of pollen - at night. In this case, the temperature at night should be in the range from +13 to $+25{ }^{\circ} \mathrm{C}$. During the day, the temperature indicators should not exceed $+35^{\circ} \mathrm{C}$. At temperatures above, tomato pollen becomes sterile, the bush sheds flowers, and ovaries are not formed. Since the temperature conditions in 2020 during the summer season, which saw the flowering of tomatoes, significantly exceeded these indicators, the yield in 2020 was record low. In the control variant, the formation of fruits was sporadic. Plants treated with alginite formed significantly more fruits, which ultimately had a positive effect on the yield. The yield in the variants treated with alginite solutions significantly exceeded the control by 316.53-327.71 g per one tomato bush.

Earlier, Brindza et al. (2021b), investigating the effect of various of alginite preparations (ultrasound-treated alginite), found that they resulted in a reduction in plant weight as well as a reduction in the average fruit weight compared to the control variant. However, our research has shown a significant increase in yield. Probably, the discrepancy between the results can be associated with the use of completely different alginite preparations: we used aqueous solutions, while Brindza et al. (2021b) - solutions from alginite treated with ultrasound.

Thus, the results of our studies showed that alginite solutions at a concentration of $0.0001-0.1 \%$ increase the germination of tomato seeds, promote an increase in seedlings and roots, and significantly increase the growth rate and productivity of plants. However, we did not add any form of alginite to the soil, but we believe that such research is worth doing in the future. It is also worth studying the effect of foliar treatments on plant growth and development. At the same time, it was reported (Gömöryová et al., 2009; Rauch and Földényi, 2012; Oravcová et al., 2018) that the introduction of alginite into the soil improves the condition of both the soil and plants. Therefore, the future research of alginite effects on the growth and development of plants by foliar treatments will be relevant. However, the treatment of plants during the growing season can affect the arthropod complex in the agrocenosis of tomatoes. This is due to the fact that, both in open field conditions and greenhouses, alginite solutions not only directly fall on insects in the agrocenosis of crops when processing plants, but can also dry out and remain on the surface of the leaf apparatus, getting inside phytophagous insects with food. Therefore, 
it is advisable to study the effect of alginite solutions on some common insects and phytophagous. Among pests at the moment in Europe, including the Republic of Moldova and the Slovak Republic, on Solanaceae crops such species as Leptinotarsa decemlineata Say (Coleoptera) and Helicoverpa armigera Hbn. (Lepidoptera: Noctuidae) are especially relevant (Elisovetcaia, 2010; Elisovetskaya and Nastas, 2012). In addition to these species, which have been known for a long time, a special role is played by the recently acclimatized, but already established themselves as extremely harmful species - the bugs Nezara viridula L. and Halyomorpha halys Stal. (Hemiptera) (Ivanova et al., 2020). Therefore, it was decided to select insect species belonging to these orders - Coleoptera, Lepidoptera, and Hemiptera - as test objects. Instead of the Helicoverpa armigera Hbn., the Galleria mellonella was selected. G. mellonella has a number of advantages over the cotton scoop: cultivation under laboratory conditions is more economical and less laborious, the degree of cannibalism in caterpillars of G. mellonella is significantly less pronounced than in caterpillars of cotton scoop. The marble bug was also selected based on the convenience of laboratory breeding.

It was revealed that alginite solutions at a concentration of $0.1-1.0 \%$ had low ovicidal properties against Halyomorpha halys -2.73 and $13.19 \%$ in terms of the percentage of sterile eggs in the control (Table 2). The ovicidal effect is most likely due not to the toxicity of alginite itself, but to its physicochemical properties. Since alginite contains a clay fraction and is able to retain water, after processing the egg-laying, it covers the ovipositions like a slime film. After drying, such a film probably prevents both free access of air and the hatching of larvae from eggs.

The insecticidal activity of alginite solutions is low and is due to the intestinal action of the drug. Therefore, when treatment the feed, the death of imago and larvae of the Colorado potato beetle ( $L$. decemlineata) was $10.0-20.0$ and $20.0-30.0 \%$, respectively, and when feeding larvae of 2-3 ages $G$. mellonella with ANM with the addition of alginite solutions, the death of insects did not exceed 5.0-10.0 \% (Table2). Probably, the insecticidal effect is due to the ingress of clay particles of alginite into the intestines of insects with feed, which subsequently leads to disruption of digestion processes and, as a consequence, to the death of insects. It was found that alginite solutions did not have contact activity with respect to insects - no death was observed with topical application of the solutions to the dorsal surface of insects (Table 2).

Despite the low insecticidal properties, alginite solutions against all species of insects showed a rather pronounced antifeedant effect (Table 2). Especially pronounced antifeedant properties were shown by 1.0-5.0 \% solutions against imagoes $L$. decemlineata $80.0-85.0 \%$. This is due to the fact that imagoes, unlike larvae, are able to tolerate longer hunger strikes. Therefore, the consumption of processed feed for imagoes decreased significantly during the experiment without significant damage to their survival. It was noted that, in comparison with the control, larvae of G. mellonella also significantly reduced feed consumption - by 51.24-68.92\%. We have previously

Table 2 Biological effects of alginite solutions on insects

\begin{tabular}{|c|c|c|c|c|c|c|c|c|c|c|}
\hline \multirow[t]{3}{*}{ Variants } & \multicolumn{4}{|c|}{ Haliomorpha halis } & \multicolumn{4}{|c|}{ Leptinotarsa decemlineata } & \multicolumn{2}{|c|}{ Galleria mellonella } \\
\hline & \multicolumn{2}{|c|}{ 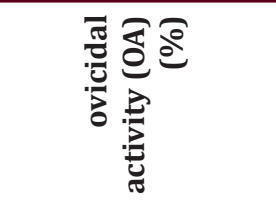 } & \multirow{2}{*}{ 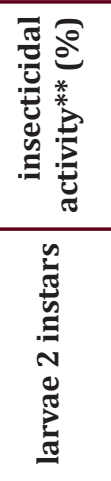 } & \multirow{2}{*}{ 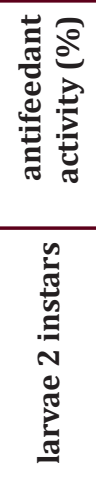 } & \multicolumn{2}{|c|}{ 胥 } & \multicolumn{2}{|c|}{ 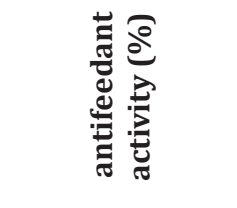 } & \multirow{2}{*}{ 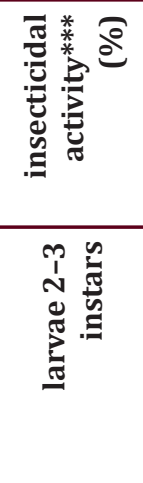 } & \multirow{2}{*}{ 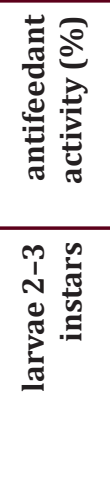 } \\
\hline & 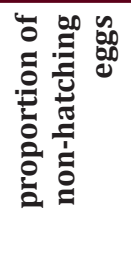 & 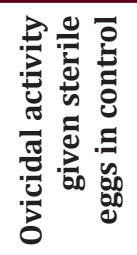 & & & 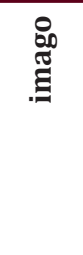 & 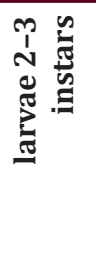 & 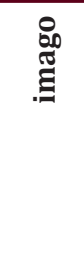 & 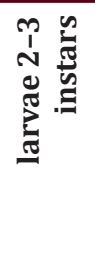 & & \\
\hline Control & $8.3^{*}$ & & 0 & 0 & 0 & 0 & 0 & 0 & 0 & 0 \\
\hline Alginite $0.1 \%$ & 11.1 & 2.7 & 0 & 20.0 & 10.0 & 20.0 & 75.0 & 45.0 & 5.0 & 51.24 \\
\hline Alginite $1.0 \%$ & 21.5 & 13.2 & 0 & 33.3 & 20.0 & 25.0 & 80.0 & 60.0 & 10.0 & 57.45 \\
\hline Alginite $5.0 \%$ & - & - & - & - & 20.0 & 30.0 & 85.0 & 60.0 & 10.0 & 68.92 \\
\hline
\end{tabular}

Notes: * proportion of sterile eggs, ${ }^{* *}$ contact insecticidal activity, ${ }^{* * *}$ intestinal insecticidal activity 
found that extracts from plants Juniperus sabina L., Cupressaceae and Pinus sylvestris L., Pinaceae are able to reduce the feed intake of G. mellonella by 47.4$84.5 \%$ (Elisovetcaia and Brindza, 2018; Elisovetcaia et al., 2019). The data obtained by us on the effect of $0.1-5.0 \%$ alginite solutions on insect nutrition revealed a sufficiently high level of antifeedant activity, comparable to the effect of plant extracts (Elisovetcaia et al., 2020).

Alginite as a bituminous rock contains a high content of silicon (Vass et al., 1997). The role of silicon (Si) on plant health has been tested under open field conditions, hydroponic cultures, and under greenhouse/ glasshouse environment (Luyckx et al., 2017). Still, presently there are a limited number of studies, which demonstrate there are advantages of Si application for greenhouse crops.

Meeting the growing demand for vegetables under situations of biotic and abiotic stresses is a big challenge. Si application is considered as an ecofriendly approach for crop production; therefore, Si application is commonly recommended under package and practices for cereals. Likewise, in vegetables, Si application has been documented to reduce the attack of diseases (Bakhat et al., 2018). For example, potassium silicate treatment of pea seedlings was observed to increase chitinase and $\beta$-1,3-glucanase activity against the fungal pathogen Mycosphaerella pinodes and it is the causes of blight disease in pea (Dann et al., 2002). Similarly, Si application has considerably reduced the root rot and powdery mildew disease in cucumber and the rust disease of cowpea (Heath and Stumpf, 1986; Chérif et al., 1994; Liang et al., 2005). Moreover, nano-silicon application can prevent postharvest diseases of vegetables (James and Zikankuba, 2017; Barman et al., 2018). In this direction, studies have also demonstrated that higher Si content in plant tissues reduced the incidence of several insect pests (Reynolds et al., 2009). Correa et al. (2005) reported that soil or as a foliar spray of $\mathrm{Si}$ as calcium silicate to cucumber plants increases the mortality of the nymphs of Bemisia tabaci.

In our experiment, we did not evaluate all the effects of alginite on tomatoes presented by Brindza et al. (2021b). However, it can be assumed that in addition to better seed germination, plant growth and other effects that we have determined when applying alginite to tomato plants, other effects can be determined. Therefore, it is useful to continue the experiments with the application of alginite to tomatoes.

\section{Conclusions}

It was found that $0.0001-0.1 \%$ alginite solutions contribute to a significant increase in the germination of tomato seeds, as well as an increase in length of seedlings and roots in comparison with the control by 1.4-3.7 times. In a greenhouse, the treatment with $0.01-0.001 \%$ alginite solutions not only increased seedlings emergence and plant height, but also contributed to a significant increase in yield compared to control. Possessing low insecticidal properties against insects, alginite solutions, at the same time lead to a decrease in damage to treated plants due to a high antifeedant effect, thereby preserving quality of aboveground part of plant and yield.

\section{Conflict of interests}

The authors declare that they have no conflict interests.

\section{Ethical statement}

This article complies with all ethical standards.

\section{Funding}

The research was carried out in frame of bilateral scholarship program between the Republic of Moldova and the Slovak Republic for 2019-2020 "Biopesticides for Pests' Management in Organic Farming" supported by grant of the Ministry of Education, Science, Research and Sport of the Slovak Republic.

\section{Acknowledgements}

The authors Elisovetcaia Dina, Ph.D. and Ivanova Raisa, Ph.D. are grateful to the Ministry of Education, Science, Research and Sport of the Slovak Republic for supporting researcher's mobility within the bilateral scholarship programs for 2019-2020.

\section{References}

Bakhat, H.F., Bibi, N., Zia, Z., Abbas, S., Hammad, H.M., Fahad, S., Ashraf, M.R., Shah, G.M., Rabbani, F., \& Saeed, S. (2018). Silicon mitigates biotic stresses in crop plants: A review. Crop Protection, 104, 21-34. https://doi.org/10.1016/j.cropro.2017.10.008

Barman, K., Sharma, S., \& Siddiqui, M.W. (2018). Emerging postharvest treatment of fruits and vegetables. CRC Press: Boca Raton, FL, USA. ISBN 978-1-351-04629-9.

Bednárová, D. (2019). Vplyv alginitu v substráte na regeneráciu a rast horčice bielej [Influence of alginite in the substrate on the regeneration and growth of white mustard]. In Ecology and Environmental Studies: Proceedings of abstracts from the $16^{\text {th }}$ year of the Student Scientific Conference. ISBN 978-80-228-3156-7. [In Slovak] 
Benei, B., \& Rauch, R. (2016). Ipari Ásványi Nyersanyagok Felhasználása a Környezetvédelemben [Use of industrial mineral raw materials in environmental protection]. In Our natural resources in the northern Hungarian regionthe migratory meeting of the MhFT. Sárospatak]. [In Hungarian]

Brindza, J., Horčinová Sedláčková, V., \& Grygorieva, O. (2021b). Active effects of less known bituminous rock alginite on the biological processes of Solanum lycopersicum L. In Genetica, fiziologia şi ameliorarea plantelor. Mat. conf. şt. intern. $7^{\text {th }}$ ed. comit. şt.: Andronic L. [et al.], Chişinău, S.n. (Print-Caro SRL). https://doi.org/10.53040/gppb7.2021.06

Brindza, J., Vozár, L., Miko, M., Gažo, J., Kovár, P., Horčinová Sedláčková, V., \& Grygorieva, O. (2021a). Unique effects of alginite as a bituminous rock on soil, water, plants and animal organisms. Agrobiodiversity for Improving Nutrition, Health and Life Quality, 5(1), 169-184. https://doi.org/10.15414/ainhlq.2021.0016

Chérif, M., Asselin, A., \& Bélanger, R.R. (1994). Defense responses induced by soluble silicon in cucumber roots infected by Pythium spp. Phytopathology, 84, 236-242.

Correa, R.S., Moraes, J.C., Auad, A.M., \& Carvalho, G.A. (2005). Silicon and acibenzolar-S-methyl as resistance inducers in cucumber, against the whitefly Bemisia tabaci (Gennadius) (Hemiptera: Aleyrodidae) biotype B. Neotropical Entomology, 34, 429-433. https://doi.org/10.1590/S1519-566X2005000300011

Cukor, J., Linhart, L., Vacek, Z., Baláš, M., \& Linda, R. (2017). The effects of Alginite fertilization on selected tree species seedlings performance on afforested agricultural lands. Central European Forestry Journal, 63(1), 48-56. https://doi.org/10.1515/forj-2017-0001

Dann, E.K., \& Muir, S. (2002). Peas grown in media with elevated plant-available silicon levels have higher activities of chitinase and $\beta$-1, 3-glucanase, are less susceptible to a fungal leaf spot stop and accumulate more foliar silicon. Australas. Plant Pathol., 31, 9-13.

Elisovețcaia, D. (2010). Extractele vegetale ca mijloc de diminuare a densităţii populaţiei Gândacului din Colorado (Leptinotarsa decemlineata Say) [Plant extracts as a means of reducing the population density of the Colorado potato beetle (Leptinotarsa decemlineata Say)]. Abstract of thesis PhD, 06.01.11 Plant protection, Chisinau. [in Romanian].

Elisovetcaia, D., Ivanova, R., Gladei, D., Simkova, J., \& Brindza, J. (2019). Biological activity of extracts from some species of coniferous plants. In $4^{\text {th }}$ International Scientific Conference "Agrobiodiversity for improve the nutrition, health and quality of human and bees life". https://doi.org/10.15414/ agrobiodiversity.2019.2585-8246.066-080

Elisovetcaia, D.S., \& Brindza, J. (2018). Effect of Secondary metabolites Juniperus sabina L. (Cupressaceae) on the survival and nutrition of caterpillars Galleria mellonella L. (Pyralidae). In Contemporary Problems of Ecology, 11(6), 594-603. ISSN 1995-4255.
Elisovetcaia, D.S., Nastas, T.N., \& Ivanova, R.A. (2020). Rastitel'nye ekstrakty $\mathrm{V}$ kachestve al'ternativnyh sredstv zashchity rastenij ot vreditelej [Plant extracts as alternative means of plant protection against pests]. In the monograph: Ecologization of the plant protection to preserve the biodiversity of insects and pollinators. Resp. ed.: R. A. Ivanova, J. Brindza. Nitra: Slovak Agricultural University in Nitra. ISBN 978-80-552-2278-3. [In Russian] https://doi.org/10.15414/2020.9788055222783

Elisovetskaya, D., \& Nastas, T. (2012). Phenology of Helicoverpa (=Heliothis) armigera (Hübner, 1808) (Lepidoptera, Noctuidae, Heliothinae) in conditions of Moldova. Oltenia. Studii şi comunicări. Ştiinţele naturii. Publisher: Museum of Oltenia Craiova, Craiova, România, 28(1), 105-110. ISSN 1454-6914, P-ISSN: 1454-6914.

Gancarčikova, S., Nemcova, R., Popper, M., Hrčkova, G., Scirankova, L., Mad'ar, M., Mudroňova, D., Vilček, Š., \& Žitňan, R. (2019). The Influence ofFeed-Supplementation with Probiotic Strain Lactobacillus reuteri CCM 8617 and Alginite on Intestinal Microenvironment of SPF Mice Infected with Salmonella typhimurium CCM 7205. Probiotics Antimicrob Proteins, 11(2), 493-508. https://doi.org/10.1007/s12602-018-9413-z

Gömöryová, E., Vass, D., Pichler, V., \& Gömöry, D. (2009). Effect of alginite amendment on microbial activity and soil water content in forest soils. Journal Biologia, Section Botany, 64(3), 585-588. https://doi.org/10.2478/s11756-009-0081-z

Heath, M.C., \& Stumpf, M.A. (1986). Ultrastructural observations of penetration sites of the cowpea rust fungus in untreated and silicon-depleted French bean cells. Physiological and Molecular Plant Pathology, 29, 27-39.

Horčinová Sedláčková, V., Šimková, J., Mňahončáková, E., Hrúzová, M., Kovár, P. Vozár, L., \& Hric, P. (2021). Effect of alginite in the form of ALGEX 6 preparation on the biomass formation and antioxidant activity of some medicinal plants. Agrobiodivers Improv Nutr Helath Life Qual, 5(1), 80-94. https://doi.org/10.15414/ainhlq.2021.0009

Ista (Intemational Seed Testing Association). (2017). International rules for seed testing, https://www. seedtest.org/en/international-rules-for-seed-testingcontent---1--1083.html

Ivanova, R.A., Elisovetskaia, D.S., \& Brindza, J. (2020). Invazivnyj klop Nezara viridula L. (Hemiptera, Pentatomidae) v Respublike Moldova [Invasive bug Nezara viridula L. (Hemiptera, Pentatomidae) in the Republic of Moldova]. In Proceedings of the International Scientific Symposium "Plant Protection: Achievements and Prospects", 27-28 October 2020], Chișinău: Căpățână Print. ISBN 978-9975-3472-0-4. [In Russian] https://doi.org/10.53040/9789975347204.11

James, A., \& Zikankuba, V. (2017). Postharvest management of fruits and vegetable: A potential for reducing poverty, 
hidden hunger and malnutrition in sub-Sahara Africa. Cogent Food \& Agriculture, 3, 1312052. https://doi.org/10.1080/23311932.2017.1312052

Kádár, I., Ragályi, P., Murányi, A., Radimszky, L., \& Gajdo, A. (2015). Effect of Gérce alginit on the fertility of an acid sandy soil. Agrokémia és Talajtan, 64(2). 437-452. https://doi.org/10.1556/0088.2015.64.2.10

Kocsis, T., Pabar, S.A., Ferschl, B., Kotroczó, Z., MohácsiFarkas, C., \& Biró, B. (2020). Biotic and abiotic risks of soil biochar treatment for food safety and human health. Acta Univ. Sapientiae, Alimentaria, 13, 69-84. https://doi.org/10.2478/ausal-2020-0004

Kovár, P., Vozár, L., Hric, P., Brindza, J., \& Verešová, P. (2021). Vplyv alginitu a extraktov z neho na klíčenie lipnice lúčnej (Poa pratensis L.) [Influence of alginite and extracts from it on germination of Kentucky bluegrass (Poa pratensis L.)]. In Proceedings: XV. národní odborný a vedecký seminár "Osivo a sadba", February $4^{\text {th }}$. ISBN 978-80-213-3080-1. [In Slovak].

Kropp, A.-C., Unz, S., Beckmann, M., Schmidt, A., Guhl, A.C., Bertau, M., Knoblich, A., \& Heide, G. (2021). Regeneration potential of alginite for the depletion of organic contaminants from wastewater. Chemie Ingenieur Technik, 93(3), 447-455.

https://doi.org/10.1002/cite.202000099

Kulich, J., Valko, J., \& Obernauer, D. (2001). Perspective of exploitation of alginit in plant nutrition. Journal of Central European Agriculture, 2, 3-4.

Kupka, I., Prknová, H., Holubík, O., \& Tužinský, M. (2015). Algae-based materials effect on mortality and initial growth plantations of the Forest tree species. Zprávy Lesnického Výskumu, 60(1), 24-28.

Liang, Y.C., Sun, W.C., Si, J., \& Römheld, V. (2005). Effects of foliar-and root-applied silicon on the enhancement of induced resistance to powdery mildew in Cucumis sativus. Plant Pathol., 54, 678-685. https://doi.org/10.1111/j.1365-3059.2005.01246.x

Luyckx, M., Hausman, J.-F., Lutts, S., \& Guerriero, G. (2017). Silicon and Plants: Current Knowledge and Technological Perspectives. Frontiers in Plant Science, 8. https://doi.org/10.3389/fpls.2017.00411
Motyleva, S., Brindza, J., Ostrovsky, R., \& Mertvicheva, M. (2014). Physical and chemical characteristics of Pincina alginate. In Advances in Materials Science Research (Numered series), Material Science, Technology and Engineering, 17, Maryann C. Wythers (ed.): NOVA. ISBN 978-1-62948-734-2.

Ognjanova-Rumenova, N., \& Vaas, D. (1998). Paleocology of the late miocene maar lakes, Podrečany basalt formation, southern Slovakia, on the basis of siliceouls microfossils. Gelologica carpathica, 49, 351-368.

Oravcová, J., Dráb, M., Ollerová, H., \& Kačík, F. (2018). Testing of Alginite as a sorbent of heavy metals from soil and above-ground biomass of plants. In Book of Proceedings: Earth in a Trap? 2018: Analytical Methods in Fire and Environmental Sciences, 23-25 ${ }^{\text {th }}$ May 2018, Zvolen, Slovak Republic. ISBN 978-80-228-3062-1.

Pichler, V., Bublinec, E., Vass, D., \& Gregor, J. (2001). Ekologicko-produkčné vlastnosti slovenského alginitu [Ecological-production properties of Slovak alginite]. Ekológia, 20(3), 278-284. [In Slovak]

Rao, N.K., Hanson, J., Dulloo, M.E., Ghosh, K., Nowell, D., \& Larinde, M. (2006). Manual of seed handling in genebanks. Handbooks for Genebanks No. 8. Bioversity International, Rome, Italy. ISBN 978-92-9043-740-6.

Rauch, R., \& Földényi, R. (2012). The effect of alginite on the decomposition of the herbicide propisochlor. J. Environ. Sci. Health B, 47(7), 670-676. https://doi.org/10.1080/03601234.2012.669212

Reynolds, O.L., Keeping, M.G., \& Meyer, J.H. (2009). Siliconaugmented resistance of plants to herbivorous insects: A review. Ann. Appl. Biol., 155, 171-186. https://doi.org/10.1111/j.1744-7348.2009.00348.x

Vass, D. (1998). Ekonomický a ekologický význam nerudných surovín v bazaltových maaroch na južnom Slovensku. Acta Montanistica Slovaca, 3(1), 59-70.

Vass, D., Konečný, V., Elečko, M., Milička, J., Snopková, P., Šucha, V., Kozač, J., \& Škrabana, R. (1997). Alginite - new source of Slovak nonmetalliferous raw materials (Pinciná deposit). Mineralica Slovaca, 29(1), 1-39. https://www. geology.sk/wp-content/uploads/documents/foto/MS/ MS-1997-29-1.pd 